\title{
Performance of a Photovoltaic or Thermal Double-Pass Solar Air Heater with Different Fin Configurations
}

\author{
Amin Elsafi and P. Gandhidasan
}

\begin{abstract}
In this paper, the steady-state performance evaluation of a double-pass flat plate hybrid photovoltaic/thermal (PV/T) solar heater with attached vertical fins of different configurations at the bottom of the absorber in the lower channel has been evaluated. A simulation model for predicting the thermal and electrical photovoltaic thermal performance of the system is presented and various performance parameters are calculated for a proposed PV/T for three straight fin profiles besides the configuration with pin fins. The effect of different fin materials has also been investigated. The simulation results showed that the use of pin fins is beneficial to achieve better performance over the design with straight fins. The model could be easily extended to cover other fin types.
\end{abstract}

Index Terms-Air, double-pass, electrical efficiency, fin, photovoltaic/thermal, solar heater.

\section{INTRODUCTION}

Hybrid PV/T systems simultaneously convert solar radiation to electricity and thermal power. The interest of this technology has been growing in recent decades, is explained by their high performance and reliability and creditability besides they work on noiseless environment [1]. As mentioned by Bakker et al. [2] the PV/T panels provide an alternative concept for low-energy housing residential market To retain the PV module electrical efficiency at acceptable level in PV/T system applications, it is important to operate them at low temperatures as it is well known that its efficiency will drop as its operating temperature increases. Therefore, a mean of cooling should be provided to maintain it at reasonable temperature. This brought the classification of the PV/T collectors, depending on the type of the working fluid, to water PV/T collector, combination of water/air PV/T collector and air PV/T collector [2]. As mentioned by Ibrahim et al. [1] and reported by Aste et al. [3], PV/T solar air heater has received much attention; though, due the lower heat capacity of the air compared with water, the heat transfer process is relatively slow.

Only a few studies have been conducted on improving $\mathrm{PV} / \mathrm{T}$ solar air heaters by using fins, corrugated absorbers and multiple-pass air flow configurations to enhance the heat transfer [3]. Among those studies is the numerical study presented by Sopian et al. [4]. The authors have investigated the performance of a double pass photovoltaic thermal solar collector suitable for solar drying applications. An interesting seminal study in this area has been made by Othman et al. [5].

Manuscript received October 24, 2013; revised January 15, 2014. This work was supported by King Fahd University of Petroleum and Minerals.

Amin Elsafi and P. Gandhidasan are with the King Fahd University of Petroleum And Minerals, Dhahran, Saudi Arabia (e-mail: amin_elsafi@ yahoo.com, pgandhi@kfupm.edu.sa).
The physical model was a flat-plate PV/T system having one glass cover and a finned absorber with the air passing through the upper channel then redirected in the opposite direction to flow through the lower channel. A detailed mathematical model for simulation has been developed for predicting the thermal performance by solving simultaneous equations. The results have been validated by experimental work for the same configuration. They concluded that utilizing the extended surfaces has a significant effect in improving both thermal and electrical output of the hybrid PV/T solar collector. Recently, Kumar and Rosen [6], [7] have presented an extension of the Othman et al. [5] model to analyze a double pass PV/T solar air heater with and without fins. The results also covered the effect of the depth of the upper and the lower channel as well as the paking factor and the inlet air temperature. The investigation showed addition of fins to the absorber will enhance the heat transfer and thereby reduces the cell temperature resulting in significantly improved in the thermal and electrical efficiencies. It is to be noted that majority past researches have not considered the effect of the fins design on the overall performance.

The objective of this paper is to assess the enhancement of the heat transfer by utilizing vertical fins attached to a double-pass PV/T collector and revealing the influence of the fins design on the thermal, electrical efficiencies by studying three different straight fin profiles besides the configuration with pin fins. Influence of the number, thickness and the material of fins on the performance of the PV/T collector has also been investigated and reported in this paper.

\section{SYSTEM DESCRIPTION}

A schematic configuration along with associated energy flows and design parameters for a conventional PV/T air heating system is shown in Fig. 1. The air enters the upper channel of the heater and the flow is directed to the lower channel in the opposite direction. As the air passes through the lower channel it is exposed to fins $(2.5 \mathrm{~cm}$ high, $100 \mathrm{~cm}$ long and thickness of $1 \mathrm{~cm}$ ) that are placed in the flow direction. The major design parameters are as follows:

$$
\begin{aligned}
& \alpha_{g 1}, \alpha_{g 2}=0.04, \alpha_{p}, \alpha_{p v}=0.92, \varepsilon_{p}=0.09, \varepsilon_{b}=0.70 \\
& \varepsilon_{g 1}, \varepsilon_{g 2}=0.85, r_{1}, r_{2}=0.04
\end{aligned}
$$

\section{MATHEMATICAL MODEL}

\section{A. Assumptions and Simplifications}

The simulation model based on energy balance on each of the collector components has been developed. In developing the analytical model, the following assumptions have been made: 


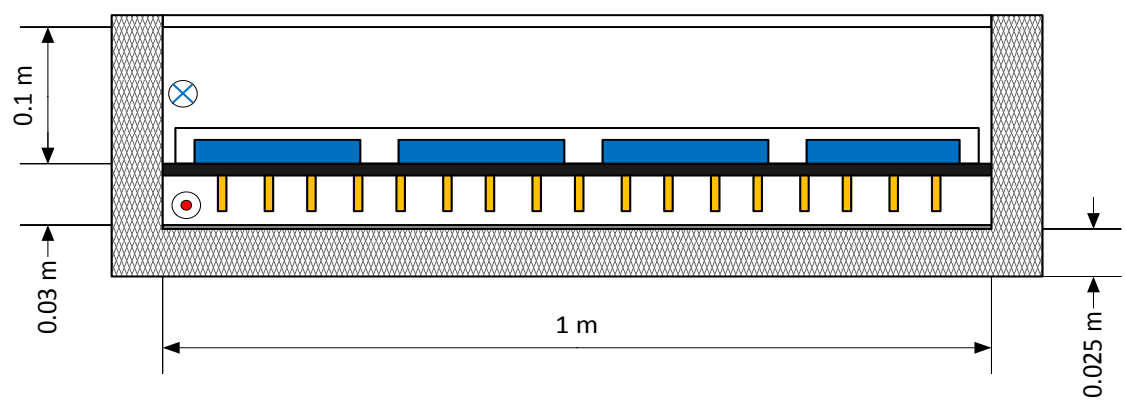

Fig. 1(a). Schematic front view of a finned double-pass PV/T solar air heater with fins.

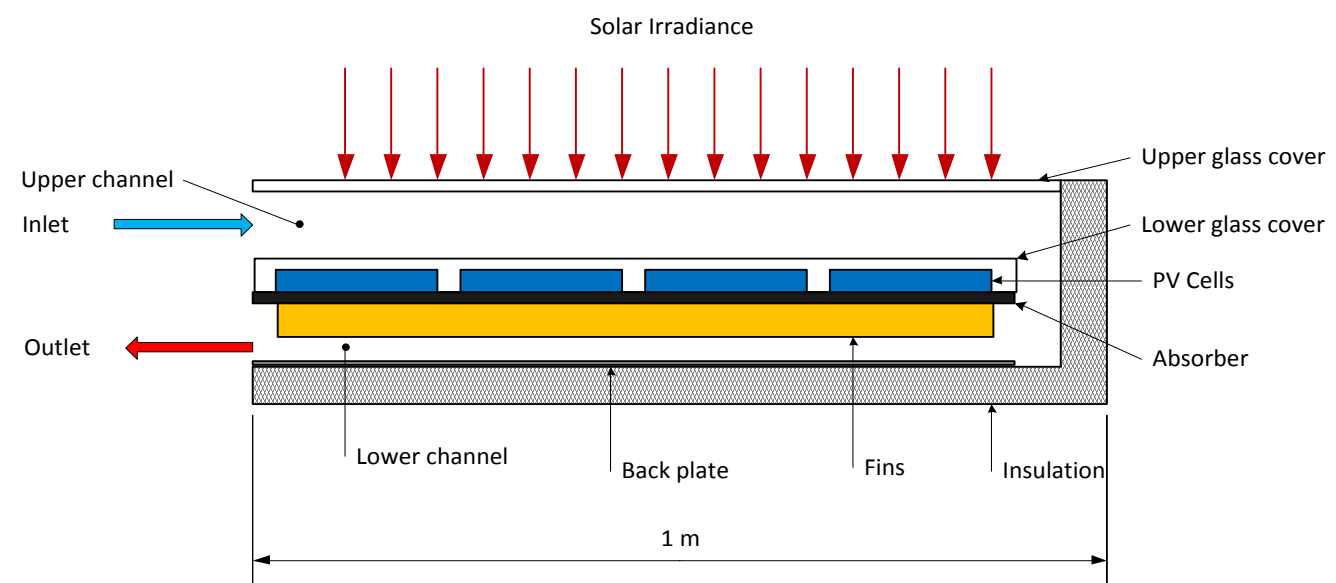

Fig. 1(b). Schematic cross-sectional view of double-pass PV/T solar air heater with fins.

1) Steady-state of energy transfer is assumed.

2) The temperature of the flowing air is varying only along the heater length.

3) The temperatures of different system components viz. glass covers, solar cell, absorber plate, and back plate vary along the direction of working fluid flow only.

4) The heat capacity of the transparent covers is very small and, therefore, it is neglected.

5) There is no leakage of air from the system.

6) Side losses from the system are negligible.

The mean absorber surface temperature is assumed equal to the PV cell temperature.

\section{B. Energy Balances}

The energy balance equations for various components of the system can be written as follows:

Upper glass cover

$$
\begin{aligned}
& I_{g 1}+h_{r, g 1-g 2}\left(T_{g 2}-T_{g 1}\right)=h_{r, g 1-s}\left(T_{g 1}-T_{s}\right) \\
& +h_{c, g 1-w}\left(T_{g 1}-T_{a}\right)+h_{c, g 1-f 1}\left(T_{g 1}-T_{f 1}\right)
\end{aligned}
$$

Lower glass cover

$$
\begin{aligned}
& I_{g 2}+h_{r, p-g 2}\left(T_{p}-T_{g 2}\right)=h_{r, g 1-g 2}\left(T_{g 2}-T_{g 1}\right) \\
& +h_{c, g 2-f 1}\left(T_{g 2}-T_{f 1}\right)
\end{aligned}
$$

Upper channel

$$
\begin{aligned}
& \frac{\dot{m} C_{p}}{W_{1}} \frac{d T_{f 1}}{d x}=h_{c-g 1, f 1}\left(T_{g 1}-T_{f 1}\right) \\
& +h_{c, g 2-f 1}\left(T_{g 2}-T_{f 1}\right)
\end{aligned}
$$

Lower channel

$$
\begin{aligned}
& -\frac{\dot{m} C_{p}}{W_{2}} \frac{d T_{f 2}}{d x}=h_{c, p-f 2} K_{1}\left(T_{p}-T_{f 2}\right) \\
& +h_{c, \mathrm{bp}-f 2}\left(T_{b p}-T_{f 2}\right)
\end{aligned}
$$

Eq. (1) to (4) can be solved simultaneously with the following boundary conditions.

$$
\text { at } x=0, T_{f 1}=T_{\text {in }}, \quad \text { at } x=L, T_{f 2}=T_{f 1}
$$

Cell surface

$$
\begin{aligned}
& I_{p}(1-P)+I_{p v} P\left(1-\eta_{e l}\right)=h_{r, p-g 2}\left(T_{p}-T_{g 2}\right) \\
& +h_{c, p-f 2} K_{1}\left(T_{p}-T_{f 2}\right)+h_{r, p-b p} K_{2}\left(T_{p}-T_{b p}\right)
\end{aligned}
$$

where $P$ is the packing factor of photovoltaic module, which is the fraction of the absorber surface occupied by the photovoltaic cells The factors $K_{1}, K_{2}$ and $\mathrm{F}_{\mathrm{o}}$ are defined as follows [8]:

$$
\begin{aligned}
K_{1} & =\eta_{o}\left(\frac{A_{o}}{A}\right) \\
K_{2} & =F_{o}\left(\frac{A_{o}}{A}\right)
\end{aligned}
$$

$$
F_{o}=\frac{1}{\frac{1}{\varepsilon_{p}}+\frac{A_{o}}{A}\left(\frac{1}{\varepsilon_{b p}}\right)-1}
$$

The forced convection heat transfer coefficient can be calculated by Candanedo et al. [9] correlations. The correlations are given as follows:

$$
N u_{\text {heated }}=0.052 \operatorname{Re}^{0.78} \operatorname{Pr}^{0.4}
$$




$$
N u_{\text {unheated }}=1.017 \operatorname{Re}^{0.471} \operatorname{Pr}^{0.4}
$$

The equations for heated plate will be used to calculate the heat transfer coefficients for the absorber/cell surface, while those for unheated are going to be used to determine the heat transfer coefficients in the back plate. The wind induced heat transfer coefficient and heat loss coefficient are calculated as given in [10]. The fin efficiencies and surface areas for rectangular, triangular and parabolic profiles can be found in any heat transfer textbook [11].

Back plate

$$
\begin{aligned}
& h_{r, p-b p} K_{2}\left(T_{p}-T_{b p}\right)=h_{c, b p-f 2}\left(T_{b p}-T_{f 2}\right) \\
& +U_{b}\left(T_{b p}-T_{a}\right)
\end{aligned}
$$

The relations for $I_{g 1}, I_{g 2}, I_{p}$ and $I_{p v}$ can be written as follows:

$$
\begin{gathered}
I_{g 1}=\left(1-r_{1}\right) \alpha_{g 1} I_{t} \\
I_{g 2}=\left(1-r_{1}\right)\left(1-r_{2}\right)\left(1-\alpha_{g 1}\right) \alpha_{g 2} I_{t} \\
I_{p}=\left(1-r_{1}\right)\left(1-r_{2}\right)\left(1-\alpha_{g 1}\right)\left(1-\alpha_{g 2}\right) \alpha_{p} I_{t} \\
I_{p v}=\left(1-r_{1}\right)\left(1-r_{2}\right)\left(1-\alpha_{g 1}\right)\left(1-\alpha_{g 2}\right) \alpha_{p v} I_{t}
\end{gathered}
$$

\section{Efficiencies}

The instantaneous thermal efficiency of the PV/T air heater is expressed as:

$$
\eta_{t h}=\frac{\dot{m} C_{p}\left(T_{f o}-T_{f i}\right)}{A I_{t}}
$$

By using Evans-Florschuetz PV efficiency correlation coefficients the electrical efficiency of the photovoltaic cells can be evaluated as follows [12]:

$$
\eta_{e l}=\eta_{o p}\left[1-0.0045\left(T_{p m}-T_{r e f}\right)\right]
$$

The mean plate temperature is given by:

$$
T_{p m}=\frac{\int_{0}^{L} T_{p} d x}{\int_{0}^{L} d x}
$$

\section{RESULTS AND DISCUSSION}

A. Performance of Straight Fins (Rectangular, Triangular, Parabolic)

The performance of the proposed collector design with ten rectangular fins is shown in Fig. 2-Fig. 4. Fig. 2 depicts the influence of the solar irradiance on the thermal efficiency at different mass flow rates. A general trend for the solar irradiance below $700 \mathrm{~W} / \mathrm{m}^{2}$ is the thermal efficiency increased with the incident solar irradiance becomes higher with the lower mass flow rates having higher thermal efficiency. As the solar irradiance reaches $700 \mathrm{~W} / \mathrm{m}^{2}$, operation of the collector at higher flow rates will results in higher efficiencies. This is trend has shown no change for the range from $700 \mathrm{~W} / \mathrm{m}^{2}$ to $1000 \mathrm{~W} / \mathrm{m}^{2}$. The thermal characteristic curve for specific climate and operating conditions has been studied and plotted in Fig. 3. As it has been expected, at a specific solar irradiance, the collector thermal efficiency will decrease as the air inlet temperature increases. When the solar irradiance is $700 \mathrm{~W} / \mathrm{m}^{2}$ and with the flow rate of $0.028 \mathrm{~kg} / \mathrm{s}$ the higher thermal efficiency, which is roughly $70.6 \%$ will be achieved when the inlet air temperature is at the ambient air temperature; $25^{\circ} \mathrm{C}$, as it has been predicted by the simulation results.

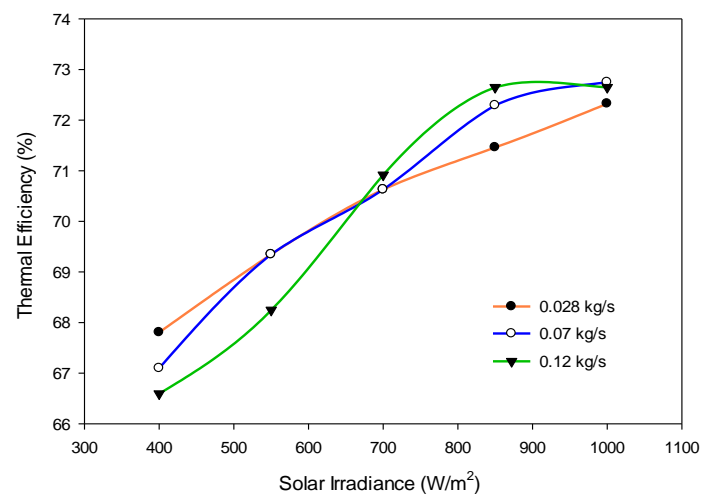

Fig. 2. Variation in the thermal efficiency with solar irradiance and air mass flow rate.

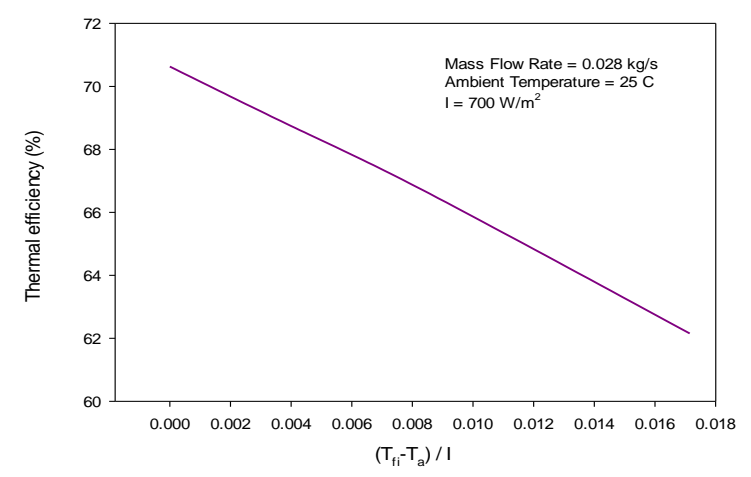

Fig. 3. Thermal characteristic curve of the proposed PV/T solar air heater.

To show the effect of the solar irradiance on the electrical efficiency of the PV panel, the simulation results has been plotted in Fig. 4. The electrical output of the PV cell decreases with higher values of solar irradiance. This can be interpreted by the fact that as the solar irradiance increases, the cells temperature increase and subsequently the electrical efficiency of the cells also decreases.

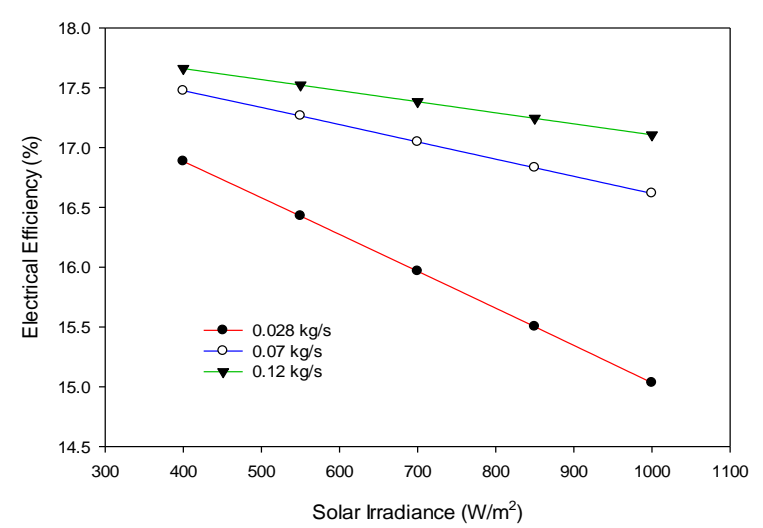

Fig. 4. Variation in the electrical efficiency of the PV cell with solar irradiance and air mass flow rate.

It is worthy to show the effect of fin design on the performance of the collector. For this purpose Fig. 5 is presented to evaluate the PV cell temperature for three different fin profiles. Over the whole range of solar irradiance 
that has been studied, the collector design with the rectangular fin profile shape was showing higher performance over the triangular and parabolic cross-sectional fin profile design. At solar irradiance of $600 \mathrm{~W} / \mathrm{m}^{2}$, the difference in performance between the three designs was barely noticed. As incident radiation reached $1000 \mathrm{~W} / \mathrm{m}^{2}$, the difference although not so large but becomes more obvious.

Fig. 5 also shows the advantage of the number of fins on the collector performance. Increasing the number of fins from 10 to 50 fins will result in a significant decrease in the cell surface temperature from $43^{\circ} \mathrm{C}$ to $36^{\circ} \mathrm{C}$. The effect is more appreciable as the solar irradiance having higher values.

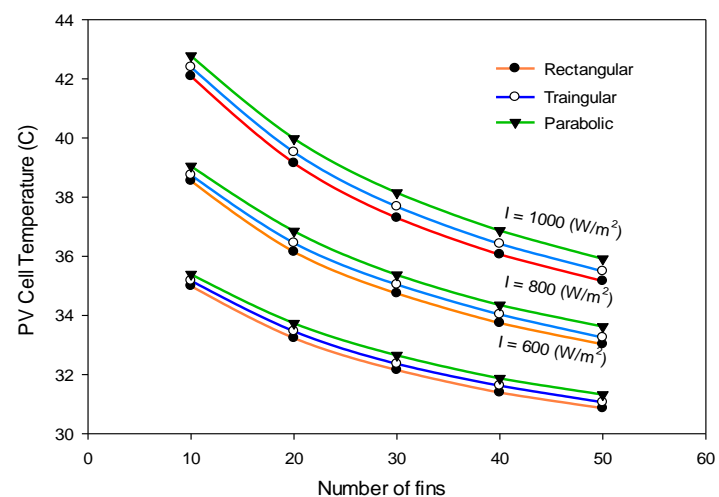

Fig. 5. Variation in the PV cell temperature with number of fins for three different fin profiles.

As the cell temperature decrease, obviously the electrical efficiency will increase and the trend is shown Fig. 6. For the current studied fin profiles there is no significant difference between the performances, yet the rectangular profile shows better performance. Fig. 6 shows the opportunity of increasing the electrical efficiency of the PV cell by utilizing and increasing the number of fins for the sites that have high solar irradiance. The electrical efficiency will drastically increase by addition of more fins. Advantage of $0.5 \%$ in the electrical efficiency could be achieved by increasing number of fins from 10 to 50 when the solar irradiance is $1000 \mathrm{~W} / \mathrm{m}^{2}$.

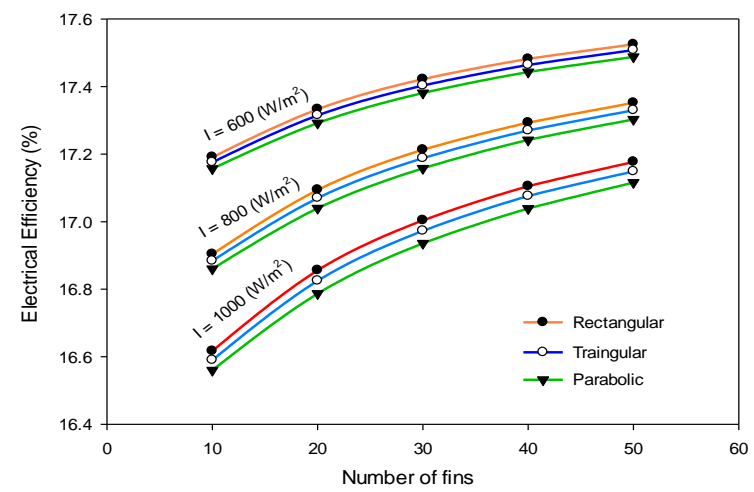

Fig. 6. Variation in the PV cell electrical efficiency with number of fins for three different fin profiles.

One way to increase the exposed fin surface area to the fluid flowing inside the collector is to make the fin thickness to increase tip's surface. Although increasing the fin thickness also will result in higher conduction resistance the results shows that will enhance the heat transfer from the absorber to the fluid. As a consequence of this trend as it shown in Fig. 7 the PV cell temperature can be lowered and the electrical efficiency can be increased. The results although not showing a huge significance by increasing the fin thickness from 1 to $5 \mathrm{~mm}$ but it might help in optimizing the design of the collector and a useful result can be noticed from Fig. 7 that increasing the fin thickness more than $4 \mathrm{~mm}$ will not help much in lowering the PV cell temperature which it might be a useful information in the design decision and mass production.

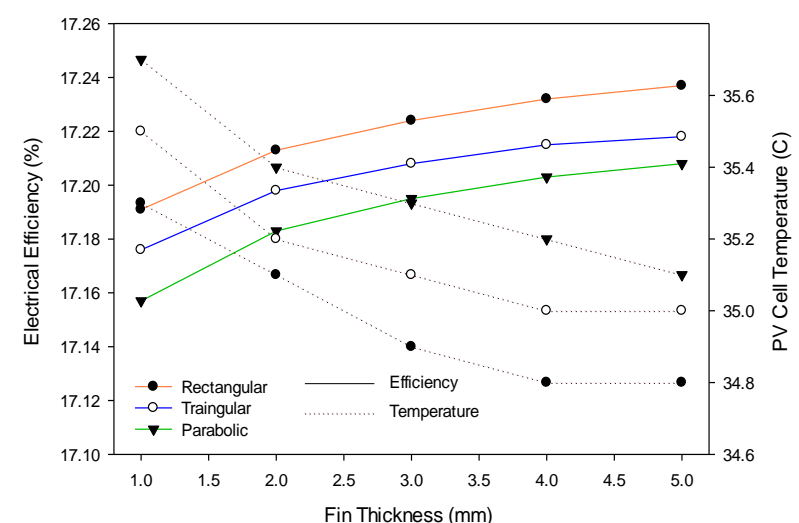

Fig. 7. Variation in the PV cell electrical efficiency with the fins thickness for three different fin profiles.

Fig. 8 and Fig. 9 show the performance comparison between five different fin materials. Fixing copper fins at the back of the absorber is predicted to reduce the absorber temperature by $1^{\circ} \mathrm{C}$ resulting in $0.6 \%$ increase of the electrical efficiency compared to the performance of the collector with steel fins. Using nickel fins also shows to improve the performance and more improvements could be achieved by using brass fins. Aluminum fins performance is predicted to be nearly as much efficient as copper fins.

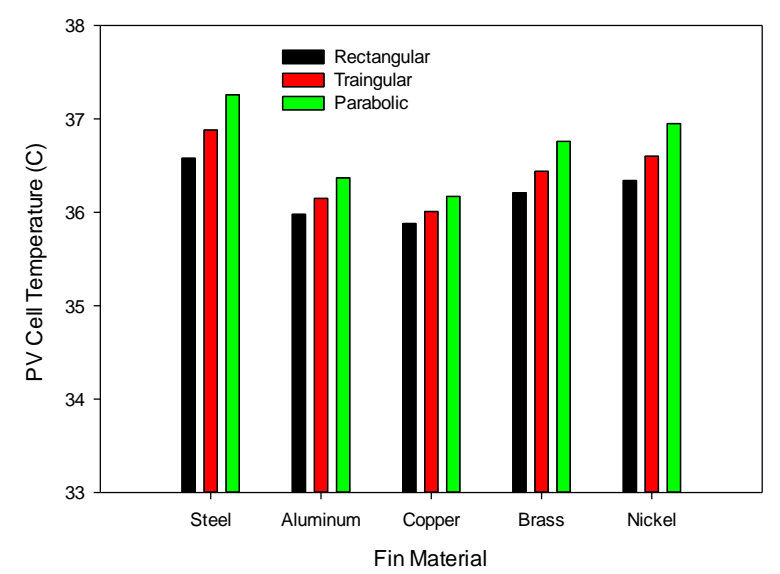

Fig. 8. Variation in the PV cell temperature for different fin materials.

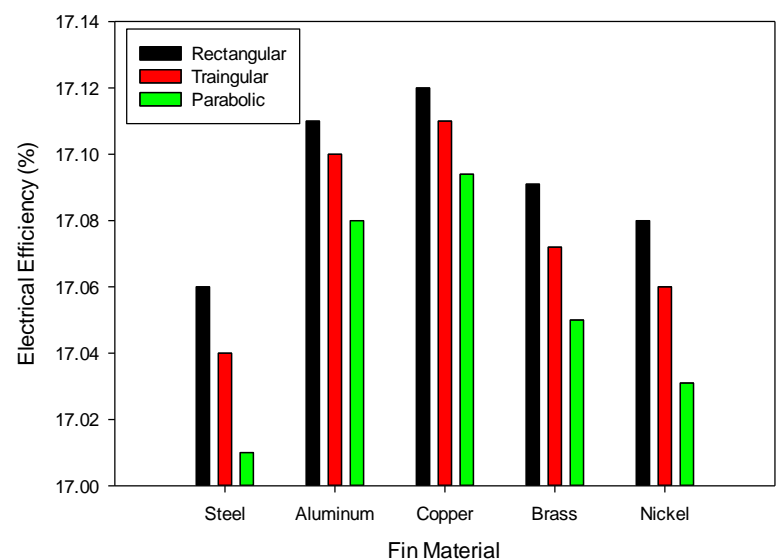

Fig. 9. Variation in the PV cell electrical efficiency for different fin materials. 


\section{B. Performance of Pin Fins}

It is beneficial to study the performance of the collector with pin fins design as they are known by their high efficiencies. In this study the collector with the same design is consider but with pin fins attached to the absorber in longitudinal and lateral directions. The pin fins diameter is fixed to $1 \mathrm{~cm}$.

The effect of the mass flow rate on the performance is presented in Fig. 10. The results can be concluded is that the improvement on the electrical efficiency of the PV module can be realized by increasing the flow rate especially when the solar irradiance is having high values. As it can be seen from Fig. 10, there is a point in which all the curve will converge on it if the curves are extrapolated. Beyond this point the mass flow rate will not play significant role in the electrical efficiency augmentation.

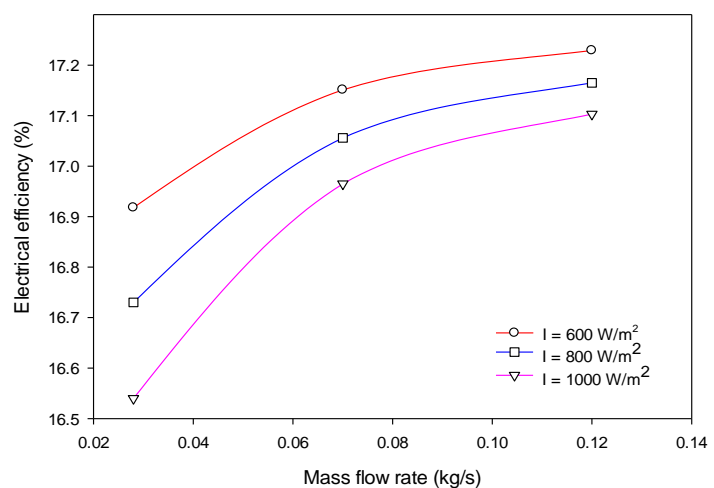

Fig. 10. Variation in electrical efficiency of the PV cell with mass flow rate.

To study the effect of the number of pin fins on the performance, the number of fins has been fixed in the lateral direction (columns) and it has been allowed to differ in the longitudinal direction (rows) as it is shown in Fig. 11. As with the straight fins, the electrical efficiency is increased by the increasing the number of fins as the exposed surface area to the flowing air will be increased. The results showed that even at high solar radiation we can achieve improvement in the electrical efficiency by increasing the number pin fins which could have not been achieved by using straight fins.

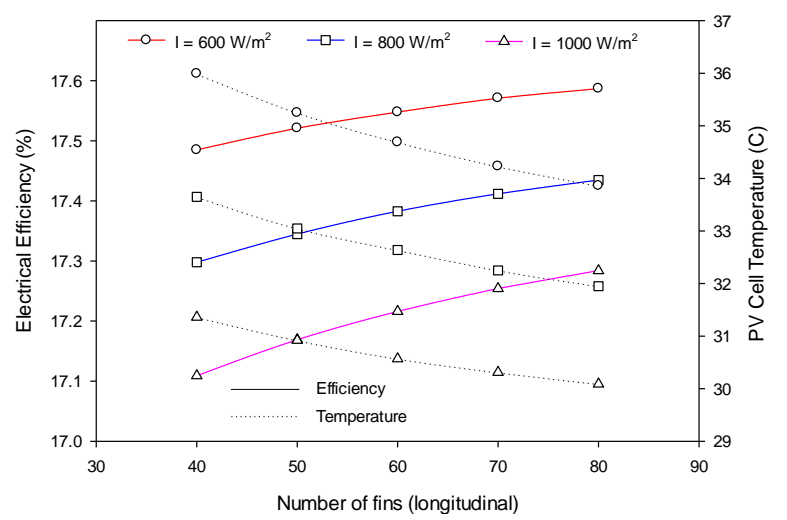

Fig. 11. Variation in electrical efficiency of the PV cell with the number of pin fins.

Table I provides a comparison between the performance straight (rectangular) fins and the pin fins. The comparison is based on the performance for the base case and the modified cases to show the advantage of increasing the number of the fins. The base case for the straight rectangular fins demonstrates the performance with 10 fins and the modified

case is the performance when the 50 fins are utilized. For the pin fin configuration the number of fins is fixed to 50 fins (rows) in the lateral direction. It is clear from the results that there is no remarkable difference in the thermal efficiency and the fluid outlet temperature when either type of fins is utilized. Nevertheless the PV module temperature is quite low for the collector with pin fins compared to the rectangular fins which results in an improvement in the electrical efficiency.

TABLE I: $\mathrm{I}=800 \mathrm{~W} / \mathrm{m}^{2}$, FLOW RATE $=0.07 \mathrm{~kg} / \mathrm{s}$

\begin{tabular}{lcccl}
\hline \hline \multirow{2}{*}{ Parameter } & \multicolumn{2}{c}{ Rectangular fins } & \multicolumn{2}{c}{ Pin Fins } \\
\hline Number of fins & 10 & 50 & $50 \times 40$ & $50 \times 80$ \\
\hline PV cell Temperature (C) & 38.55 & 33.02 & 33.65 & 31.95 \\
Electrical Efficiency (\%) & 16.90 & 17.35 & 17.30 & 17.44 \\
\hline \hline
\end{tabular}

\section{CONCLUSIONS}

The performance of PV/T solar air heater has been predicated by developing a mathematical model applicable for simulation. The study aimed to show the effect of utilizing fins as a mean for heat transfer enhancement to achieve better electrical efficiency PV cells by reducing the absorber/cell temperature. The characteristic curve for the proposed finned-absorber collector has been predicated and the influence of the number of the fins on the performance has been revealed for the same collector but with rectangular, triangular, parabolic fin profiles as well as pin fins. The study also shows the performance of the collector at different mass flow rates and different solar irradiance. Although the studied straight fin profiles show no big difference in the performance, the design with rectangular fins profile has shown always better performance over the triangular and the parabolic profiles. Increasing the fin thickness may improve the electrical efficiency, yet the simulation results show that it has no significant influence in the performance. Selection of the fin materials also help in the endeavor of the performance improvement as some fin materials like aluminum is predicted to be more capable of enhancing the heat transfer process between the PV cell surface and the working fluid. The simulation results showed that the use of pin fins is beneficial to achieve better performance over the design with straight fins.

\section{NOMENCLATURE}

A

$A_{0}$

$C_{p}$

$F_{0}$

$h$

$I$

$L$

$\dot{m}$

$\mathrm{Nu}$

$P$

$\operatorname{Pr}$

$\dot{Q}$

$R e$

$r_{1}$

$r_{2}$

$T$ area of absorber $\left(\mathrm{m}^{2}\right)$ overall surface area of absorber and fins $\left(\mathrm{m}^{2}\right)$ specific heat of air $(\mathrm{J} / \mathrm{kg}-\mathrm{K})$ shape factor heat transfer coefficient $\left(\mathrm{W} / \mathrm{m}^{2}-\mathrm{K}\right)$ solar irradiance $(\mathrm{W} / \mathrm{m} 2)$ length of air heater $(\mathrm{m})$ mass flow rate $(\mathrm{kg} / \mathrm{s})$ Nusselt nimber packing factor Prandtl numbr net heat transferred $\left(\mathrm{W} / \mathrm{m}^{2}\right)$ Reynolds number reflectance of upper glass reflectance of lower glass temperature (C) 
$U \quad$ loss coefficient $\left(\mathrm{W} / \mathrm{m}^{2}-\mathrm{K}\right)$

$W_{1} \quad$ width of upper air channel (m)

$W_{2} \quad$ width of lower air channel (m)

$x \quad$ variation of distance in the direction of $\mathrm{L}$

\section{Greek letters}

$\begin{array}{ll}\alpha & \text { absorptance } \\ \varepsilon & \text { emissivity } \\ \eta & \text { efficiency }\end{array}$

\section{Subscripts}

$\begin{array}{ll}a & \text { ambient } \\ b & \text { bottom insulation } \\ b p & \text { back plate } \\ c, g 1-f 1 & \text { convective upper to air } \\ c, g 2-f 1 & \text { convective lower glass to air } \\ c, g 2-w & \text { convective upper glass to ambient } \\ c, p-f 2 & \text { convective absorber surface to air in lower } \\ & \text { channel }\end{array}$

c, $b p-f 2$ convective back plate to air in lower channel

el electrical

$f 1 \quad$ air in upper channel

$f 2$ air in lower channel

fi air at inlet

fo air at outlet

$g 1 \quad$ upper glass

g2 lower glass

II second law efficiency

$o \quad$ overall heat surface

op nominal efficiency of photovoltaic cell

$p \quad$ absorber surface

$P \quad$ packing factor

pm mean absorber temperature

ref reference temperature

pv photovoltaic cell

$r, g 1-g 2$ radiative upper to lower glass

$r, g 1-s \quad$ radiative upper glass to sky

$r, p-b p \quad$ radiative absorber to back plate

$r, p-g 2$ radiative absorber to lower glass

$s \quad$ sky

$t$ total

th thermal

\section{ACKNOWLEDGMENT}

The authors are grateful for the financial support and facilities provided by King Fahd University of Petroleum and Minerals.

\section{REFERENCES}

[1] A. Ibrahim, M. Y. Othman, M. H. Ruslan, S. Mat, and K. Sopian, "Recent advances in flat plate photovoltaic/thermal (PV/T) solar collectors," Renewable and Sustainable Energy Reviews, vol. 15, issue 1, pp. 352-365, 2011.

[2] M. Bakker, H. Zondag, M. Elswijk, K. Strootman, and M. Jong, "Performance and costs of a roof-sized PV/thermal array combined with a ground coupled heat pump," Solar Energy, vol. 78, issue 2, pp 331-339, 2005.

[3] N. Aste, G. Chiesa, and F. Verri, "Design, development and performance monitoring of a photovoltaic-thermal (PVT) air collector," Renewable Energy, vol. 33, issue 5, pp. 914-927, 2008.

[4] K. Sopian, H. Liu, S. Kakac, and T. Veziroglu, "Performance of a double pass photovoltaic thermal solar collector suitable for solar drying systems," Energy Conversion and Management, vol. 41, issue 4, pp. 353-365, 2000.

[5] M. Y. Othman, B. Yatim, K. Sopian, and M. N. A. Bakar, "Performance studies on a finned double-pass photovoltaic-thermal (PV/T) solar collector," Desalination, vol. 209, issue 1-3, pp. 43-49, 2007.

[6] R. Kumar and M. A. Rosen, "Performance evaluation of a double pass PV/T solar air heater with and without fins," Applied Thermal Engineering, vol. 31, issue 8-9, pp. 1402-1410, 2011.

[7] M. A. Rosen and R. Kumar, "Performance of a Photovoltaic/Thermal Solar Air Heater: Effect of vertical fins on a double pass system," International Journal of Energy and Environmental Engineering, vol. 2, pp. 1-1, 2011.

[8] H. Garg, G. Datta, and B. Bandyopadhyay, "A study on the effect of enhanced heat transfer area in solar air heaters," Energy Conversion and Management, vol. 23, issue 1, pp. 43-49, 1983.

[9] L. M. Candanedo, A. Athienitis, and K. W. Park, "Convective heat transfer coefficients in a building-integrated photovoltaic/thermal system," Journal of Solar Energy Engineering, vol. 133, issue 2, 2011.

[10] J. A. Duffie and W. A. Beckman, Solar Engineering of Thermal Processes, 4th ed., John Wiley \& Sons Inc. 2013.

[11] F. P. Incropera, A. S. Lavine, and D. P. DeWitt, Fundamentals of Heat and Mass Transfer, John Wiley \& Sons Incorporated. 2011.

[12] E. Skoplaki and J. Palyvos, "On the temperature dependence of photovoltaic module electrical performance: a review of efficiency/power correlations," Solar Energy, vol. 83, issue 5, pp. 614-624, 2009.

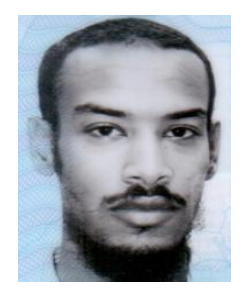

Amin Elsafi received his BSc. degree in mechanical engineering from University of Khartoum, Sudan, in 2009. He is now a MSc. candidate in the Department of Mechanical Engineering at King Fahd University of Petroleum and Minerals (KFUPM), Dhahran, Saudi Arabia.

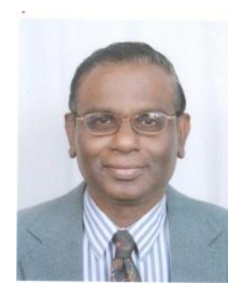

P. Gandhidasan is a professor of mechanical engineering at King Fahd University of Petroleum and Minerals (KFUPM), Dhahran, Saudi Arabia. He received his $\mathrm{PhD}$ in mechanical engineering from the Indian Institute of Technology, Madras, in 1979. He has over 34 years of teaching and research experience and has published over 100 technical journal/conference papers. 